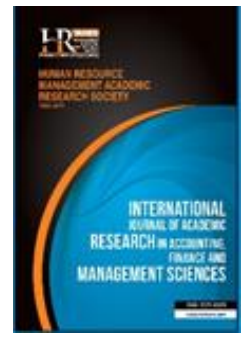

International Journal of Academic Research in Accounting, Finance and Management Sciences

Vol. 8, No.2, April 2018, pp. 218-227

E-ISSN: 2225-8329, P-ISSN: 2308-0337

(C) 2018 HRMARS

www.hrmars.com

To cite this article: Al Shbail, M.O. (2018). A Theoretical Discussion of Factors Affecting the Internal Audit Quality in Jordanian Public Shareholding Companies, International Journal of Academic Research in Accounting, Finance and Management Sciences 8 (2): 218-227.

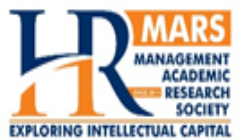

http://dx.doi.org/10.6007/IJARAFMS/v8-i2/4273 (DOI: 10.6007/IJARAFMS/v8-i2/4273)

\title{
A Theoretical Discussion of Factors Affecting the Internal Audit Quality in Jordanian Public Shareholding Companies
}

\author{
Mohannad Obeid AL SHBAIL \\ Al-Albayt University, Jordan \\ E-mail: Mohannadobeid87@gmail.com
}

\begin{abstract}
Scholars have not been in agreement in terms of the influencing factors of internal auditing quality and the best way for measuring them, and most notably, the framework that is most fitting for internal audit quality. The lack of attention to the theories in literature may be the cause of the disagreement. Therefore, factors impacting the internal audit quality among public shareholding companies, particularly in Jordan have been proposed based on past works. As such, a hypothetical model is proposed in this study. The model scrutinizes the internal audit quality and its antecedents including premature sign-off, job satisfaction, Job burnout and the stressors in internal auditing environment; all these greatly contribute to the understand the factors effecting on internal audit quality in such companies. It is anticipated that this study will offer valuable insights for the future works.
\end{abstract}

Key words Premature sign-offs, internal audit quality, job burnout, job satisfaction, public shareholding companies, Jordan

$\begin{array}{lll}\text { Received: } & 14 \text { Jun } 2018 \quad \text { C The Authors } 2018 \\ \text { Revised: } & 02 \text { Jul } 2018 \quad \text { Published by Human Resource Management Academic Research Society (www.hrmars.com) }\end{array}$

Accepted: 09 Jul 2018 This article is published under the Creative Commons Attribution (CC BY 4.0) license. Anyone may Published Online: $20 \mathrm{Jul} 2018$ reproduce, distribute, translate and create derivative works of this article (for both commercial and noncommercial purposes), subject to full attribution to the original publication and authors. The full terms of this license may be seen at: http://creativecommons.org/licences/by/4.0/legalcode

\section{Introduction}

Internal auditing is currently regarded as "an independent, objective guarantee and consulting activity that is created to contribute value to and enhance the operations of the organizations. It assists an organization to achieve its objectives by developing a systematic, disciplined method to analyze and enhance the effectiveness of organizational processes including risk management, control and governance" (Institute of Internal Auditors, 2011). Furthermore, the internal audit functionappeared to have diminished in terms of its importance from its peak after the issuance of Foreign Corrupt Practices Act (FCPA) in 1977 and therefore, the Sarbanes-Oxley Act (SOX) was introduced in 2002 in order to reinforce FCPA (Gray et al., 2015). As for SOX's impact on internal audit, the internal auditors are perceived by management as their control experts following SOX implementation (Gray, 2004). Further, it has been acknowledged by the 1992 COSO Internal Control - Integrated Framework the crucial role played by internal auditors in organization. However, the crucial roles played by internal auditors are mentioned more in the revised 2013 coso Framework. Among the mentions include the statement: "Internal auditors provide the third line of defense in assessing and reporting on internal control and recommending corrective actions or enhancements for management consideration and implementation; their position and compensation are separate and distinct of the business areas they review" (COSO 2013). 
It is not uncommon to see the concept internal audit quality being elucidated with respect to defects or non-compliance against standards (CIIA, 2015). This is the reason why internal audit quality was regarded to be a main issue. Thus, the concept is made up of a substantial amount of literature on internal audit quality, especially, after some leading companies including Enron, WorldCom, and Parmalat collapsed due to scandals in the early 2000s. This has led to a pressing requirement for internal audit quality particularly in finding out irregularities such as fraud. For instance, auditor is accountable to detect and report fraud as well as other illegal activities. Also, consistency is crucial; auditor is also responsible determine if "the conclusions drawn from different types of evidence are consistent with one another." Hence, the factors that led to the collapse of major firms were reviewed by regulatory authorities of accounting auditing. In order to reestablish confidence in the accounting profession, the Sarbanes Oxley Act was launched in the U.S. after passing both houses of Congress. Thus, there should be studies on audit quality so that the factors that contribute to and create sub-standard audit quality could be ascertained. Correspondingly, this paper presents theoretical evidence on the factors that affect internal audit in terms of quality.

Internal audit is mostly grounded on the attainments of the individual internal auditors that are involved with the process. Thus, as indicated by (Alzeban, 2015), it is important to concentrate on the factors that may impact the performance of internal auditors, which will translate to the quality of internal audit. As the past experimental and survey studies have demonstrated, pressures in the audit environment contribute to dysfunctional behaviours among individual auditors which contributes to lower audit quality. Such pressures therefore transcend the firm's quality control mechanisms and at the audit engagement level, this impacts quality. The quality of audit of external audits has been the focal point of the majority of past research. On the other hand, the internal audit quality of public shareholding companies is yet to be scrutinized.

Unethical behavior demonstrated by internal auditors adversely impacts the quality of internal audit (Obeid et al., 2017), and this in turn impacts an entity in terms of its external audit (Ling and Akers, 2010). As suggested by the past empirical evidence, burnout has impact on unethical behaviour of auditors (Kingori, 2016). Internal auditors that have to deal with significant amount of pressure from the work environment could experience burnout (Fogarty and Kalbers, 2006b; Kalbers and Fogarty, 2005; Larson, 1997, 2011; Obied et al., 2018). Unfortunately, it is often that the problem is not detected until it becomes serious.

Add to this, as mentioned by a large amount of past studies, burnout impacts internal auditors' dysfunctional behavior which causes significant inefficiency on either organization or individual. Absenteeism, turnover intention, and reduced productivity are among these behaviours (Fogarty and Kalbers, 2006b; Kalbers and Fogarty, 2005; Larson, 1997, 2011). It was also mentioned by other researchers in public accounting including Fogarty et al. (2000), Murtiasri and Ghozali (2006), Jones et al. (2010), Chong and Monroe (2015) and Kingori (2016) that the relationship between job stressors and job outcomes is mediated by burnout. In other words, the increase of pressure on antecedent factors increases job stressors. This will increase the intensity of burnout which will cause auditors to dysfunction.

As indicated by the past arguments, job burnout will mediate the relationship between stressor in internal audit environment and critical outcomes pose influence on internal audit quality. As such, the focal point of this study is the factors may impact internal audit quality in Jordan from behavioural view point.

\section{Factors That Influence on Internal Audit Quality in Public Shareholding Companies}

The frequent news on corporate scandals involving auditors makes it reasonable for one to feel that auditors have lost their moral compass (Everett and Tremblay, 2014). Also, internal auditors being a gatekeeper of the corporate governance have not been able to stop the global financial crisis from happening. The 2013 UK's banks' LIBOR scandal is one such example; this case comprises a major fraud committed by a trading bank reported (Chambers et al., 2015). In the context of Malaysia, the review of internal audit is important in decreasing the majority of fraud incidents. For instance, Ghazali et al. (2014) reported ineffective internal control as the major reason in the majority of fraud incidents in Malaysia in both state and local entities. 
As reported by (O'Leary and Stewart, 2007), ethical failings shown by auditors can have extensive economic impacts and lead to widespread financial distress. The need to elucidate the notion of audit quality has sparked interests among scholars to scrutinize the effect of ethical behavior especially after the incidences of accounting scandals and financial crisis that have impacted the majority of economies globally (Zureigat, 2011). A strategy is thus necessitated so that of internal audit quality of high level could be sustained as it could generate financial statements of high quality. Several factors that can weaken auditor's independence, integrity and professional judgment have been discussed by Everett and Rahaman (2012). These factors include the ideological, political and moral factors that internal auditors have to deal with in combating fraud and corruption.

For the situation of Jordan, the collapses caused by financial frauds that had happened in the majority of countries of the world have caused the feeling of doubts in terms of the credibility of the listed companies' operating and financial reporting procedures (Al-Sraheen and Nawwaf, 2014). Consequently, in order to improve the financial reporting quality, certain reforms and practices have been suggested by several professionals, organizations, regulatory entities and scholars. These include focusing on the principle of conservatism and usage of optimized corporate governance mechanisms and also increasing the quality of audit (Adeyemi and Fagbemi, 2010; Hamdan, 2011a; 2011b; Hamdan et al., 2012) .

Further, Davidson and Neu (1993) mentioned audit quality as among the main factors that affect the financial information in terms of credibility. Zureigat (2011) added that higher audit quality contributes to the generation of correct information. Besides, audit quality is among the many critical concerns within the domain of auditing and capital market. As reported by (Francis, 2004; Ghorbanpour et al., 2014), auditing failures have obviously occured on the lower end of the quality scale. Therefore, audit quality should be scrutinized in order to determine the factors that contribute to mediocre or lower than mediocre quality in an audit (Ghorbanpour et al., 2014).

Conversely, each country's context nature might impact the quality of application of international professional standards for internal audit (Abdullatif and Kawuq, 2015). As for Jordan, it is a developing nation with a small economy. Businesses running in Jordan are mostly of the fairly small and closely held type owned mostly by families. In general, this governance system is applicable even to a huge number of public listed companies in Jordan. These companies are inclined to comprise of small amount of major shareholders controlling their executive management, alongside the many small shareholders (Abdullatif and Kawuq, 2015). As indicated by (Abdullatif and Al-Khadash, 2010), the systems of corporate governance in Jordanian companies are typically weak, with transparency and disclosure of financial information that are restricted. Further, the disposition of the Jordanian companies and their system of governance causes the difference in the application of internal auditing function in comparison to what is practiced in the more-developed countries as companies operating in these countries tend to be considerably bigger and possess corporate governance, internal auditing, and practices of risk management that are more developed.

Conversely, the audit comprises different structural dimensions in terms of quality, and this is hard to evaluate due to a number of factors that are believed to impact the quality of the audit. As such, there should be a framework for its determination (Ghorbanpour et al., 2014). Also, more studies should be conducted on audit quality considering the nature of economic market in Jordan and the markets of the developing countries (Al Sawalqa, 2014; Zureigat, 2011b).

A culture of ethical adherence and awareness of ethical adherence between internal auditors and Jordanian firms should be promoted (Al Hosban, 2015). In fact, companies in Jordan have to improve their internal audit function(Bagulaidah, 2012). As example, (Shanikat, 2014) indicated companies in Jordan do not practice formal fraud risk assessments and rewards for whistle-blowers to prevent fraud. As articulated by AbdAlla et al. (2013), pressure on internal auditors should be decreased, which may lead to get a better performance from them. As proposed by the authors, future studies should look into factors that will make better the quality and effectiveness of the internal audit in Jordan. As demonstrated by Sweidan and Zurayq (2013), improvement has been weak and internal audit work quality necessitates adjustment in the Jordanian electricity companies. Ja'arah (2012) also indicated the need for more research to detect the role of the auditor himself in playing the part in the incident of fraud in Jordan. It should be noted that studies 
in this domain conducted in Jordan were mostly centering on the aspect of procedures and regulation of the audit profession (Zureigat, 2011a).

Financial statement that is accurate and timely highly contributes to the success of many organizations (Apadore and Noor, 2013). The role of investors is identical to that of an accountant in the generation of timely financial information. However, having to produce timely audited annual reports or financial statements puts auditors under pressure (Apadore and Noor, 2013). In relation to this, Salehi and Ghaderi (2012) mentioned the increasing complexity of business transactions to have generated pressure on the internal audit profession. This has caused business failures as exemplified in cases involving Satyam Group in India, AIG, Enron and Lehman Brother in USA, Transmiles and Megan Media in Malaysia. Stressors generate substantial negative consequences on internal auditors, for instance, it causes increase in premature sign-offs (Azad, 1994); (Obied et al., 2018). In fact, among internal auditors, premature sign-offs widely occurs (ibid). Premature sign-off impacts internal audit in terms of quality and also affects external audit providing that the external auditor depends on the internal audit department's work (Ling and Akers, 2010). Conversely, Nehme (2013) studied 350 London Stock Exchange listed companies and concluded that most auditors show dysfunctional behavior (e.g. A premature sign-offs) in performing their task. The author also indicated that most auditors are aware their dysfunctional behavior to attain better performance. Nehme (2013) further added that certain demonstrations of dysfunctional behavior are caused by a misperception of the concept of dysfunctional behaviour during an audit assignment while pressures from audit firms such as performance evaluation, time deadline and time budget can spark internal auditors' premature sign-offs.

Past researches (e.g. Almer and Kaplan, 2002; Chong and Monroe, 2015; Fogarty and Kalbers, 2006; Fogarty et al., 2000; King'ori, 2016; Obeid et al., 2018; Sweeney and Summers, 2002; Ussahawanitchakit et al., 2009) mentioned job burnout as a crucial factor impacting behaviour of employees. In fact, job burnout has been found to be closely associated to numerous familiar behavioural and attitudinal accounting outcomes. Firms should be aware of the causes and consequence of factors linked to behavioural and attitudinal outcome so that matters regarding employee turnover with respect to costs and maintenance of the human resources. Within the context of human resource, the important aspect is that it helps in the preservation of the firm's competitive advantage (Fogarty and Kalbers, 2006a; Kalbers and Fogarty, 2000). Somehow, albeit these factors' substantial effect on employees' behaviours, more research should be carried on the impact of job burnout on the premature sign-offs of internal auditors. Because this deviant behaviour it is most frequent among internal auditors (Ling and Akers, 2010; Obeid et al., 2017). With the awareness on the antecedents of job burnout, the management of companies could create policies that would reduce the impact of job burnout and costs associated to turnover, absenteeism and diminished productivity can be saved (Utami and Nahartyo, 2012).

As reported by Kickul and Posig (2001), theorganization's existing operating and economic conditions significantly affect the work demands and responsibilities of employees. As organizations irrespective of location are being downsized, outsourcing and restructuring, employees in every level experience stress, uncertainty, confusion, undervaluation and alienation. As reported by Lindstrom et al. (1997) such swift changes in organizations together with the changes in information technology have created more complex situation for the employees; employees have to deal with increased workloads and pressures and decreased job control. This, as reported by Lindstrom et al. (1997) has been linked to employee strain. Employee that could not endure occupational pressures anymore and feel absolutely overwhelmed by stress is prone to reach breaking point and feel burnout (Weisberg, 1994).

Add to this, the turbulent work environment also affects the shareholding companies. The late twentieth century has seen the significant expansion of shareholding companies owing to speedy economic growth, urbanisation and popular education (Bun, 2002). This has prompted serious competitiveness and rivalry between employees as well as between companies (Lai et al., 2000). All these, combined with intensified pressure to perform (Chan, 2 002; Lai et al., 2 000), tension, mistrust, interpersonal relationship strain (Lai et al., 2000), psychological strain, fatigue as well as tension (Lindstrom et al., 1997) can result. All these, impact the behaviour of employees.

\section{The Conceptual Model}


The research model introduced in this study is an adaptation from the work of Parker and DeCotiis (1983) that has two outcomes level. The model generates comprehensive understanding of the factors that impact internal audit quality. Further, it can be regarded as a rudimentary framework. This is because in order to attain improved internal auditors in terms of quality in their businesses tasks, it is important that public shareholding companies to first ascertain the variables. The model comprises of four (6) variables: stressors (role ambiguity and role conflict), Job burnout, job satisfaction, premature sign-off and internal audit quality. These variables are shown in Figure1. A simple model is favourable among public shareholding companies because the simplicity will ease usage. All of the selected constructs, which are justified by a review of literature, are important in the comprehending and explaining the decision of public shareholding companies to have better internal audit quality.

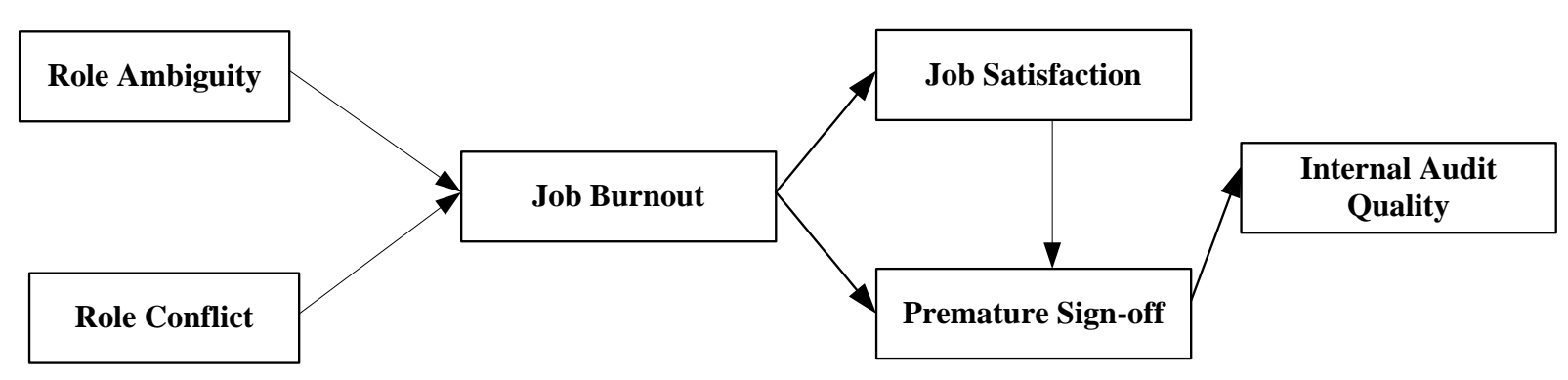

Figure 1. The conceptual Model

As this study aims to introduce a model for the crucial factors that impact the internal audit quality in the public shareholding companies in Jordan. Thus, following research hypotheses are proposed.

\subsection{Role Conflict and Role Ambiguity and Job Burnout}

Role ambiguity is the lack of specificity and predictability in the job of the employee or in his role functions and responsibilities (Kahn et al., 1964; Beehr, 1976). While, role conflict occurs when the individual is expected to behavior in a way that contradicts with its requirements, capacity and his values (Viator, 2001).

Many studies evidenced the positive association between role conflict and job burnout (e.g. Fogarty et al., 2000; Jones et al., 2010). Additionally, role conflict results in an emotionally-charged workplace that is characterized by high effort levels. Role conflict also leads to a high burnout possibility in public accounting and internal audit context (Chong and Monroe, 2015; Fogarty and Kalbers, 2006; Fogarty et al., 2000; Fogarty and Kalbers, 2006; Fogarty et al., 2000, Jones et al., 2010; King'ori, 2016; Murtiasri and Ghozali, 2006). Specifically, role conflict leads to role environments characterized by high levels of emotions, where high effort levels are needed for tasks performance. The persistence of such an environment over different role episodes could mean burnout for professionals (Maslach and Jackson, 1984). Similarly, unclear roles in terms of goals and direction could lead to burnout owing to the employee's performance of tasks under role ambiguous conditions and the energy and mental resources needed that the situation requires (Maslach, 1982). This energy drain coupled with persistent emotional excitement could lead to burnout feelings (Jackson et al., 1986).

On other hand, the top role stressors that cause burnout are role ambiguity in the context of internal audit as evidenced by Fogarty and Kalbers (2006). In relation to the above, in Larson's (2004) study, he showed that role ambiguity is bound to be present when there is lack of a clear objective, plan or expectation, or there is lack of feedback provided to the employees and thus, confusion reigns. Literature shows also that role ambiguity negatively impacts several outcomes including job satisfaction and employee motivation (e.g., Behrman and Perreault Jr., 1984; Aghghaleh et al., 2014; Kalbers and Cenker, 2008; Schuler et al., 1977). Thus, following research hypotheses are proposed;

H1a: High perceived role conflict will be associated with an increase in job burnout. 
H1b: High perceived role ambiguity will be associated with an increase in job burnout.

\subsection{Burnout, Job satisfaction and Premature Sign-Off}

Several outcomes have been derived resulting from burnout, including job satisfaction (Chong and Monroe, 2015; Low et al., 2001; Silbiger et al., 2017; Ybema et al., 2010). Jones et al. (2010) and Cordes and Dougherty (1993) demonstrated that role stress and burnout adversely impact individuals and lead to dissatisfaction on jobs. Similar findings have been found by Chong and Monroe (2015) who revealed that job-related tension relates to job burnout which in effect, decreases the employees' job satisfaction, in which case dissatisfied employees are more likely to search for other alternative jobs. Some other studies showed that lowered burnout lead to increased satisfaction on the job and outcomes of auditor's work (e.g. Fogarty et al., 2000; Jones et al., 2000; Almer and Kaplan, 2002).

Conversely, job burnout is a significant factor that impacts the behaviours of auditors (Fogarty et al., 2000; Almer and Kaplan, 2002; Sweeney and Summers, 2002; Fogarty and Kalbers, 2006; Chong and Monroe, 2015; King'ori, 2016). As indicated by Larson (1997), the effects of burnout that professionals experienced may include dysfunctional behaviours. Such reasoning was further expanded by Persellin et al. (2015). The authors reported a positive linkage between workload and the perceptions of burnout as well as an association between workload and a following decrease in audit quality. In relation to this, Smith et al. (2007) also reported a negative association between one of the decomposed elements of burnout (reduced personal accomplishment) and job performance. Further, burnout appears to have substantial negative linkage with job performance and a significant positive linkage with turnover intentions (Fogarty et al., 2000). On the other hand, Smith et al. (2007) did not report any significant association between burnout and job performance. Thes present study agree with the argument provided by Smith and Emerson (2017), which state that once a person's coping mechanisms have been overcome, and burnout has occurred, they will become more susceptible to engaging in reduced audit quality practices (e.g., dysfunctional audit behaviours). In support to this argument, King'ori (2016) reported a strong positive linkage between job burnout and premature sign-off. Further, Smith and Emerson (2017) found a positive direct effect of burnout on reduced audit quality practices. Thus, it is hypothesized that job burnout ought is directly proportional with premature sign-off. Considering the above arguments and explanations, therefore, the following hypotheses are proposed;

H2a: High job burnout levels are related with low satisfaction.

H2b: High job burnout levels are related with high number of premature sign-offs.

\subsection{Job Satisfaction and Premature Sign-Off}

As mentioned, internal auditing is often a very stressful profession owing to the heavy workloads, deadlines and time and resource restrictions (Azad, 1994). Also, internal auditors are almost frequently pressured to come up with quality work within a restricted budget, time-wise and resources-wise (Brown and Mendenhall, 1995). Auditing tasks also often involve many traveling and varying work locations which could increase the stress levels even more (Sears, 1992). Also, as auditors have to consistently deal with auditees in stressful circumstances, their mental and physical processes may be negatively impacted (Chau, 1998). Thus, low level of job satisfaction substantially antecedes adverse employee behavior (Martin and Miller, 1986). Likewise, dissatisfied individual towards the promotion opportunities afforded him or her in the internal audit function could demonstrate behaviors and outcomes including reduced commitment, reduced satisfaction with the job, and intent to leave internal audit (Quarles, 1994).

The relationship in light of the Social Exchange theory was elucidated by Homans (1961). The author stated that employees that experience job dissatisfaction may be prone to engage in deviant behavior as revenge against the employers for not providing fitting work environment. This deviant behavior is also explainable by dissatisfied employees who feel no concern over losing their jobs. Conversely, satisfied employees steer clear from deviant behavior that could cause them to lose their jobs.

Indeed, many studies linked between deviant behavior and job satisfaction. For instance, Bennett and Robinson (2003), Bowling (2010), Reisel et al. (2010) and Obeid et al. (2017) concluded the linkage 
between job dissatisfaction and deviant behavior. Bowling (2010) in particular, stated that dissatisfied employees have higher inclination to engage in deviant behavior as a way to release stress. The metaanalysis by Dalal (2005) and Srivastava (2012) supports the negative correlation between both variables. Thus, the hypothesis below is to be proposed:

H3: Low level of job satisfaction is related with increased premature sign-offs.

\subsection{Premature Sign-Off and Internal Audit Quality}

Within the accounting literature, the prevalent dysfunctional audit behaviors among auditors is a huge concern in both internal and external audit (e.g. Azad, 1994; Brown-Liburd and Wright, 2011; Kingori, 2003, 2016; Ling and Akers, 2010; Paino et al., 2010; Paino et al., 2012; Obeid et al., 2017, 2018; Soobaroyen and Chengabroyan, 2006; Yuen et al., 2011; Yuniarti, 2012), owing to the fact that these behaviors increase pressure to the workplace environment of auditors which could cause the auditor to have reduced control over such environment (Pierce and Sweeney, 2006).

Dysfunctional behavior in this context is unfitting behavior as it goes against the standards of audit (Kelly and Margheim, 1990; Otley and Pierce, 1996). Premature sign-off in auditing, time under-reporting or modifying procedures of auditing are among the examples of dysfunctional behaviour (Otley and Pierce, 1996), which could lead to negative outcomes and impact audit quality (Mindarti and Puspitasari, 2014). In particular, premature sign-off comprises auditor skipping steps, that is, he skips the stages of audit program (Alderman and Deitrick, 1982). Premature sign-offs can give adverse impact towards quality of audit work by internal auditors (Azad, 1994; Ling and Akers, 2010). As such, the hypothesis we propose is.

H6: Premature sign-offs is related to low internal audit quality.

\section{Conclusions}

This paper presents the background work on internal audit quality and the existing challenges that internal auditors in public shareholding companies have to deal with. This paper presents the development of the conceptual model which becomes the foundation of the study using the past studies as basis. The model includes four (2) stressors impacting the internal auditor's job burnout. Also, the relationship between job burnout and job satisfaction, job burnout and premature sign-off, job burnout and internal audit quality, and the relationship between job satisfaction and premature sign-off and premature sign-off and internal audit quality is presented by the model. Somehow, empirical testing is yet to be conducted on the factors. Using this study as guide, the forthcoming studies can create testable hypotheses, generate more precise research questions and offer comprehensive in terms of practice and theory with respect to internal audit quality. Further, the proposed theoretical framework could also be employed in the forthcoming studies to allow more scrutiny into the topic. This study views internal audit as assisting in the attainment of its objectives. Thus, the study suggested applicable theories to shed some light on the argument aside from gaining better awareness of the effect of the proposed factors that impact the internal audit quality within the realm of public shareholding companies.

\section{References}

1. AbdAlla, A. A. J., Othman, O. H., \& Mssadeh, A. A. D. (2013). The Impact of Internal Control to Ecommerce Activities on the Quality of Internal Auditing in the Financing Companies Operating in Jordan. International Research Journal of Finance and Economics (108), 104-114.

2. Abdullatif, M., \& Al-Khadash, H. A. (2010). Putting audit approaches in context: The case of business risk audits in Jordan. International Journal of Auditing, 14(1), 1-24.

3. Abdullatif, M., \& Kawuq, S. (2015). The role of internal auditing in risk management: evidence from banks in Jordan. Journal of Economic and Administrative Sciences, 31(1), 30-50.

4. Adeyemi, S. B., \& Fagbemi, T. O. (2010). Audit quality, corporate governance and firm characteristics in Nigeria. International Journal of Business and Management, 5(5), 169. 
5. Al-Sraheen, D. a. A.-D., \& Nawwaf, O. (2014). The relationship between corporate governance mechanisms and company attributes and accounting conservatism of Jordanian listed companies. Universiti Utara Malaysia.

6. Al Hosban, A. A. (2015). The Role of Regulations and Ethics Auditing to Cope with Information Technology Governance from Point View Internal Auditors. International Journal of Economics and Finance, 7(1), 167.

7. Al Sawalqa, F. (2014). External Audit Services Quality and Client Satisfaction: Evidence from Jordan. Research Journal of Finance and Accounting, 5(12), 223-236.

8. Almer, E. D., \& Kaplan, S. E. (2002). The effects of flexible work arrangements on stressors, burnout, and behavioral job outcomes in public accounting. Behavioral Research in Accounting, 14(1), 1-34.

9. Alzeban, A. (2015). The Impact of Culture on the Quality of Internal Audit An Empirical Study. Journal of Accounting, Auditing \& Finance, 30(1), 57-77.

10.Apadore, K., \& Noor, M. M. (2013). Determinants of Audit Report Lag and Corporate Governance in Malaysia. International Journal of Business and Management, 8(15), p151.

11.Azad, A. N. (1994). Time budget pressure and filtering of time practices in internal auditing: a survey. Managerial Auditing Journal, 9(6), 17-25.

12.Bagulaidah, G. S. S. (2012). The Determinants of Audit Report Lag: The Mediating Effect of Auditor's Reliance in Jordan. Universiti Utara Malaysia.

13.Bennett, R. J., \& Robinson, S. L. (2003). The past, present, and future of workplace deviance research.

14.Bowling, N. A. (2010). Effects of job satisfaction and conscientiousness on extra-role behaviors. Journal of Business and Psychology, 25(1), 119-130.

15.Brown-Liburd, H. L., \& Wright, A. M. (2011). The effect of past client relationship and strength of the audit committee on auditor negotiations. Auditing: A Journal of Practice \& Theory, 30(4), 51-69.

16.Brown, D., \& Mendenhall, S. (1995). Stress and components of the internal auditor's job. Internal Audit, 10, 31-31.

17.Bun, C. K. (2002). Coping with work stress, work satisfaction, and social support: An interpretive study of life insurance agents. Asian Journal of Social Science, 30(3), 657-685.

18.Chambers, A. D., Odar, M., \& Martinov-Bennie, N. (2015). A new vision for internal audit. Managerial Auditing Journal, 30(1).

19.Charterd Institute of Internal Auditors CIIA. (2015). Quality and internal audit. Available at SSRN::https://www.iia.org.uk/resources/quality-and-internal-audit/

20.Chong, V. K., \& Monroe, G. S. (2015). The impact of the antecedents and consequences of job burnout on junior accountants' turnover intentions: a structural equation modelling approach. Accounting \& Finance, 55(1), 105-132.

21.Committee of Sponsoring Organizations of the Treadway Commission COSO. (2013). Internal Controllntegrated Framework. Jersey City, NJ: AICPA.

22.Davidson, R. A., \& Neu, D. (1993). A Note on the Association between Audit Firm Size and Audit Quality*. Contemporary Accounting Research, 9(2), 479-488.

23.Everett, J., \& Rahaman, A. S. (2012). This paper is the original manuscript and has not been revised or edited. For the final version, see the French translation.

24.Fogarty, T. J., \& Kalbers, L. P. (2006a). Internal auditor burnout: An examination of behavioral consequences. Advances in Accounting Behavioral Research, 9, 51-86.

25.Fogarty, T. J., \& Kalbers, L. P. (2006b). Internal auditor burnout: An examination of behavioral consequences. Advances in Accounting Behavioral Research, 9(1), 51-86.

26.Fogarty, T. J., Singh, J., Rhoads, G. K., \& Moore, R. K. (2000). Antecedents and consequences of burnout in accounting: Beyond the role stress model. Behavioral Research in Accounting, 12, 31-67.

27.Francis, J. R. (2004). What do we know about audit quality? The British Accounting Review, 36(4), 345-368.

28.Ghorbanpour, Z., Dehnavi, H. D., \& Heyrani, F. (2014). Examination of Auditor Acceptance of Dysfunctional Behavior Using a Heuristic Model. International Journal of Academic Research in Accounting, Finance and Management Sciences, 4(1), 41-51. 
29.Gray, G. L. (2004). Changing internal audit practices in the new paradigm: the Sarbanes-Oxley Environment: Inst of Internal Auditors.

30.Gray, G. L., Yoon, K., No, W. G., \& Roebuck, P. (2015). Comparing the Attitudes and Activities of Internal Auditors in Australia, Canada, and the United States Regarding Green IT.

31.Hamdan, A. M. M. (2011a). Evaluation of level of accounting conservatism in financial statements and its relationship to corporate governance in companies listed in Kuwait stock exchange. Journal of King Saud University, Administration Sciences, 23(2), 253-284.

32. Hamdan, A. M. M. (2011b). The impact of company size, debt contracts, and type of sector on the level of accounting conservatism: an empirical study from Bahrain. International Journal of Business and Management, 6(7), 134.

33.Hamdan, A. M. M., Kukrija, G., Awwad, B. S. A., \& Dergham, M. M. (2012). The Auditing Quality and Accounting Conservatism. International Management Review, 8(2), 33.

34. Homans, G. C. (1961). Social behavior: Its elementary forms.

35.Ja'arah, O. O. (2012). Methods of the External Auditor in Detecting Fraud in the Financial Statements of Public Shareholding Companies. Derasaat, Management Science, Middle East University, Jordan., 39(2).

36.Jones, A., Norman, C. S., \& Wier, B. (2010). Healthy lifestyle as a coping mechanism for role stress in public accounting. Behavioral Research in Accounting, 22(1), 21-41.

37.Kalbers, L. P., \& Fogarty, T. J. (2000). Why Do Internal Auditors Burnout? An Investigation of Individual and Organizational Explanations (February 22, 2000). Available at SSRN: https://ssrn.com/ abstract $=213608$.

38.Kalbers, L. P., \& Fogarty, T. J. (2005). Antecedents to internal auditor burnout. Journal of managerial issues, $17(1), 101-118$.

39.Kickul, J., \& Posig, M. (2001). Supervisory emotional support and burnout: An explanation of reverse buffering effects. Journal of managerial issues, 328-344.

40.Kingori, J. (2016). Burnout and Auditor Work Behaviours in Tanzanian Public Accounting Firms. Business Management Review, 11(1), 65-97.

41.Lai, G., Chan, K. B., Ko, Y. C., \& Boey, K. W. (2000). Institutional context and stress appraisal: The experience of life insurance agents in Singapore. Journal of Asian and African studies, 35(2), 209-228.

42.Larson, L. (1997). Internal auditor job stress and turnover intentions. Cleveland State University.

43.Larson, L. (2011). Gender differences in internal auditor job burnout. Internal Auditing-Boston, 26(1), 11.

44.Lindstrom, K., Leino, T., Seitsamo, J., \& Torstila, I. (1997). A longitudinal study of work characteristics and health complaints among insurance employees in VDT work. International Journal of Human-Computer Interaction, 9(4), 343-368.

45.Ling, Q., \& Akers, M. (2010). An Examination of Underreporting Of Time And Premature Signoffs By Internal Auditors. Review of Business Information Systems.

46.Low, G. S., Cravens, D. W., Grant, K., \& Moncrief, W. C. (2001). Antecedents and consequences of salesperson burnout. European Journal of Marketing, 35(5/6), 587-611.

47.Murtiasri, E., \& Ghozali, I. (2006). Anteseden dan Konsekuen Burnout. Simposium Nasional.

48.Nehme, R. (2013). Dynamics of Audit Quality: Behavioural Approach and Governance Framework: UK Evidence. Durham University.

49.0'Leary, C., \& Stewart, J. (2007). Governance factors affecting internal auditors' ethical decisionmaking: an exploratory study. Managerial Auditing Journal, 22(8), 787-808.

50.Obeid, M., Salleh, Z., \& Mohd Nor, M. (2017). The Mediating Effect of Job Satisfaction on The Relationship Between Personality Traits and Premature Sign-off. Academy of Accounting and Financial Studies Journal, 21(2), 1-17.

51.Obied, M., Salleh, Z., \& Mohd Nor, M. (2018). The effect of ethical tension and time pressure on job burnout and premature sign-off. Journal of Business and Retail Management Research, In press.

52.Parker, D. F., \& DeCotiis, T. A. (1983). Organizational determinants of job stress. Organizational behavior and human performance, 32(2), 160-177. 
53.Persellin, J., Schmidt, J. J., \& Wilkins, M. S. (2015). Auditor perceptions of audit workloads, audit quality, and the auditing profession. Working Paper.

54.Pierce, B., \& Sweeney, B. (2006). Perceived adverse consequences of quality threatening behaviour in audit firms. International Journal of Auditing, 10(1), 19-39.

55.Reisel, W. D., Probst, T. M., Chia, S.-L., Maloles, C. M., \& König, C. J. (2010). The effects of job insecurity on job satisfaction, organizational citizenship behavior, deviant behavior, and negative emotions of employees. International Studies of Management \& Organization, 40(1), 74-91.

56.Salehi, M., \& Ghaderi, A. R. (2012). A Study of Job Satisfaction between External and Internal Auditors: An Iranian Scenario. Research Journal of Applied Sciences, Engineering and Technology, 4.

57.Schaufeli, W., \& Enzmann, D. (1998). The burnout companion to study and practice: A critical analysis: CRC press.

58.Shanikat, M. M. (2014). Occupational Fraud Prevention Mechanisms: Jordanian Companies Experience. Research Journal of Finance and Accounting, 5(1).

59.Silbiger, A., Berger, R., Barnes, B. R., \& WS Renwick, D. (2017). Improving expatriation success: the roles of regulatory focus and burnout. British Journal of Management, 28(2), 231-247.

60.Smith, K. J., Davy, J. A., \& Everly, G. (2007). An assessment of the contribution of stress arousal to the beyond the role stress model. Advances in Accounting Behavioral Research, 10, 127-158.

61.Smith, K. J., \& Emerson, D. J. (2017). An analysis of the relation between resilience and reduced audit quality within the role stress paradigm. Advances in Accounting, 37, 1-14.

62.Soobaroyen, T., \& Chengabroyan, C. (2006). Auditors' Perceptions of Time Budget Pressure, Premature Sign Offs and Under-Reporting of Chargeable Time: Evidence from a Developing Country. International Journal of Auditing, 10(3), 201-218.

63.Srivastava, S. (2012). Workplace passion as a moderator for workplace deviant behaviour-job satisfaction relationship: A comparative study between public sector and private sector managers. AsiaPacific Journal of Management Research and Innovation, 8(4), 517-523.

64.Sweidan, M., \& Zurayq, B. A. (2013). Compliance with international internal audit standards in the Jordanian electricity companies. Jordanian Journal of Business Administration, 9(3), 540-565.

65.Utami, I., \& Nahartyo, E. (2012). Type Personality Moderating Effect on The Influence of Role Stressors on Burnout. Paper presented at the Ponencia presentada en International Conference on Business and Management. Phuket-Thailand.

66.Viator, R. E. (2001). The association of formal and informal public accounting mentoring with role stress and related job outcomes. Accounting, Organizations and Society, 26(1), 73-93.

67.Weisberg, J. (1994). Measuring workers' burnout and intention to leave. International Journal of Manpower, 15(1), 4-14.

68.Ybema, J. F., Smulders, P. G., \& Bongers, P. M. (2010). Antecedents and consequences of employee absenteeism: A longitudinal perspective on the role of job satisfaction and burnout. European Journal of Work and Organizational Psychology, 19(1), 102-124.

69.Yuen, C. Y., Law, K. F. P., Lu, C., \& Guan, J. (2011). Dysfunctional Auditing Behaviour: A Research on Auditors' Behaviour in Macau.

70.Yuniarti, R. (2012). The Effect of Tenure Audit and Dysfunctional Behavior on Audit Quality. Paper presented at the International Conference of Economics, Business and marketing Management.

71.Zureigat, Q. M. (2011a). The effect of ownership structure on audit quality: Evidence from Jordan. International Journal of Business and Social Science, 2(10).

72.Zureigat, Q. M. (2011b). The effect of ownership structure on audit quality: Evidence from Jordan. International Journal of Business and Social Science, 2(10), 38-46. 